UDK: 37.013.42-053.4

Stručni rad

\title{
SOCIJALNA KOMPETENTNOST U RANOJ I PREDŠKOLSKOJ DOBI
}

\section{Martina Župančić}

Samobor

Republika Hrvatska

tinica292@gmail.com

\section{Alen Hasikić}

Fakultet za odgojne i obrazovne znanosti Sveučilište Jurja Dobrile u Puli

Republika Hrvatska

alen.hasikic@unipu.hr 


\section{SAŽETAK}

U radu se determinira konstrukt socijalne kompetencije s gledišta različitih autora. Rezultati raznih istraživanja pokazali su da djeca s razvijenom socijalnom kompetencijom ostvaruju bolje akademske rezultate $i$ imaju veće samopouzdanje. Stoga se u radu tumači važnost odgojno-obrazovnih radnika i uloga obitelji u razvijanju socijalnih kompetencija djece predškolske dobi. Uz to, u radu su prikazana recentnija istraživanja socijalne kompetencije u odnosu na rodne razlike i sociometrijski status $i$ prijateljstvo.

Ključne riječi: socijalna kompetencija, odgojno-obrazovni radnik, uloga obitelji. 


\section{UVOD}

Pojam socijalne kompetentnosti često se definira kao najvažnija kompetencija za kvalitetan i ispunjen suživot s drugima. Također, od izuzetne je važnosti, kako za interpersonalno komuniciranje, tako i za intrapersonalno funkcioniranje. Od najranije dobi uočava se potreba za razvijanjem socijalnih vještina svakog djeteta kao pojedinca uzimajući u obzir djetetovu osobnost, talente, obitelj, okruženje, socijalne prilike te djetetov potencijal za buduće funkcioniranje u društvu i zajednici. Autori često naglašavaju ulogu rane i predškolske dobi za razvoj socijalne kompetencije, jer će se upravo u razdoblju prije polaska u školu razviti ponašajni obrasci kojima će dijete biti izloženo po modelu odrasle osobe.

Kako bi se pobliže objasnila važnost socijalne kompetentnosti i zašto se upravo socijalnim kompetencijama mnogi stručnjaci bave, govori i longitudinalno istraživanje s Harvarda ${ }^{\mathbf{1}}$ koje se provodilo kroz 80 godina. Rezultati pokazuju kako su za kvalitetan i uspješan život na mnogim područjima zaslužni upravo odnosi s ljudima. Dakle, socijalna kompetentnost koja se očituje u suradnji, rješavanju problema, empatiji, kvalitetnim odnosima uz postizanje vlastitih ciljeva, prepoznavanju vlastitih potreba i prepoznavanju tuđih, djelovat će i na druge aspekte života te naposljetku na kvalitetu života.

\section{DEFINIRANJE POJMA SOGIJALNA KOMPETENTNOST}

Prema mnogim autorima socijalna kompetentnost, kao jedna od ključnih kompetencija, očituje se u sposobnostima prilagođavanja i fleksibilnosti uz korištenje svojih znanja i vještina za što bolje funkcioniranje u društvu. Tako će prema Katz i McClellan (2005) socijalno kompetentna osoba iskoristiti poticaje i svoje osobne potencijale i postići dobre razvojne rezultate (Katz i McClellan, 2005).

Socijalna kompetencija poistovjećuje se sa socijalnom odgovornošću, komunikacijom, suradnjom, sposobnošću rješavanja konflikata te reagiranjem primjereno situaciji (Božin i sur., 2011). S obzirom na to da je socijalna kompetentnost prepoznata kao jedna od ključnih kompetencija koje je potrebno razvijati tijekom obrazovanja, Markuš (2010) ističe složenost tog konstrukta koji se odnosi na djelotvorno funkcioniranje pojedinca u socijalnom kontekstu uz istovremeno uspješno postizanje osobnih ciljeva. O djelotvornosti u socijalnom kontekstu govori i Brdar (1993) naglašavajući kako su upravo to sposobnosti koje olakšavaju početak, razvijanje i održavanje odnosa među ljudima.

1 Preuzeto na: https://news.harvard.edu/gazette/story/2017/04/over-nearly-80-years-harvard-studyhas-been-showing-how-to-live-a-healthy-and-happy-life/ (1.10.2020.) 


\section{SOCIJALNE VJEŠTINE}

Suvremeno društvo sve više prepoznaje važnost uspješne interakcije $s$ drugima i uspostave kvalitetnih profesionalnih i osobnih odnosa. Markuš (2010) ističe kako socijalna kompetentnost i socijalne vještine dijele neka zajednička obilježja, no potrebno ih je razlikovati. Socijalne vještine obuhvaćaju specifična ponašanja pojedinaca (npr. tolerantnost, nenasilno rješavanje sukoba, konstruktivnu komunikaciju i slično), dok socijalna kompetencija određuje način na koji pojedinac koristi vještine u socijalnoj okolini. Može se reći da je pojedinac socijalno kompetentan ako na prihvatljiv način koristi socijalne vještine $\mathrm{i}$ istovremeno uspješno postiže ključne osobne ciljeve.

Socijalna kompetencija, prema Sindik (2008), obuhvaća dvije temeljne sposobnosti, a to su: razumijevanje drugih ljudi i razborito postupanje u međuljudskim odnosima.

\section{SOCIJALNA KOMPETENCIJA U VRTIĆKOM KONTEKSTU}

U razvijanju socijalnih vještina te poticanju cjelokupnog razvoja djeteta $\mathrm{u}$ odgojno-obrazovnom procesu naglašava se važnost kompetentnosti i svestranosti odgojno-obrazovnih djelatnika. Zašto je to tako govore i autori Vasta, Haith i Miller (1997) koji ističu kako se velik dio ljudskog ponašanja, posebice prosocijalno ponašanje, stječe, a ne dobiva rođenjem. Stoga, činjenica da se prosocijalno ponašanje, pa tako i socijalne kompetencije ne dobivaju rođenjem nego se stječu, omogućuju djelovanje. Mlinarević i Tomas (2010) o socijalnoj kompetenciji u vrtićkom kontekstu govore kao prvoj instituciji socijalizacije nakon obiteljskog doma te važnoj i ključnoj sredini za buduće interpersonalne odnose u životu djece. Modrić (2013) govori o kvalitetnom funkcioniranju u socijalnom kontekstu koje, prema McClellan i Katz (2001), zahtijeva temelje već u prvih pet ili šest godina života. Djeca koja do šeste godine nisu usvojila minimalnu socijalnu kompetenciju u odrasloj dobi vrlo vjerojatno će se ponašati rizično. Od osobite je važnosti „rano i kontinuirano usvajanje stavova, komunikacijskih i socijalnih vještina kroz primarne i sekundarne društvene skupine u kojoj dijete odrasta i usvaja obrasce društveno poželjnog ponašanja “ (Vlah, 2013, 58). Živčić-Bečirević i suradnici (2003) prikazuju osnovne zadatke predškolske dobi od kojih usvajanje samokontrole i samopouzdanja čini osnovu socijalnih vještina kroz kontakte s vršnjacima, pojedincima i skupinom, sve do kontrole emocija.

Postoje pokazatelji da socijalno kompetentna djeca postižu bolje rezultate u 
akademskim postignućima, stvaraju kvalitetne odnose kroz bolju komunikaciju te imaju veće samopouzdanje (Pahl i Barrett, 2007). Slično, Gouley i suradnici (2008) povezuju veću socijalnu kompetentnost sa sveobuhvatnim razvojem djeteta $\mathrm{u}$ raznim područjima. Čimbenici koji su ključni za razvoj socijalne kompetencije u predškolskoj dobi su: obitelj, vršnjaci, igra i učenje, simbolička igra, zajednica, vrijeme, promjene u fizičkom okruženju, vrijeme u kojem se djeca mogu družiti, projektni rad, interakcije odgojitelja s djetetom te partnerstvo roditelja i odgojitelja (Mlinarević i Tomas, 2010). Uz navedene čimbenike isti autori naglašavaju i važnost individualnog rada s djecom kao najoptimalnijeg načina učenja. Uključenost u pojedinu situaciju rezultirat će razumijevanjem, usvajanjem i primjenjivanjem socijalnih vještina. Shodno tome, valja postaviti pitanje koliko su uvjeti u predškolskim ustanovama naklonjeni individualnom radu uzimajući $\mathrm{u}$ obzir brojnost djece u skupinama. Također, odgojitelji i nastavnici koji rade s djecom u vrtićima, domovima i školama govore o činiteljima koji potiču rizična ponašanja, a suprotna su od prosocijalnih ponašanja kod djece. To su: toleriranje društva rizičnih i nemoralnih ponašanja, izostanak svakodnevne primjerene brige roditelja o djeci, izostanak pozitivne komunikacije među vršnjacima kao i marginaliziranje odgojne uloge škole (Zloković i Vrcelj, 2010). Velik broj ispitanika u ovom istraživanju (čak $73 \%$ odgojitelja/nastavnika) ističe kako imaju osjećaj vlastite nemoći i općenito osjećaj indiferentnosti društva prema djeci, koji se javljaju sukladno poteškoćama kao što su nepotpunost stručno-razvojnih službi, nemotiviranost suradnika te preopterećenost nastavnika/odgojitelja brojnim administrativnim poslovima.

\section{ULOGA OBITELJI U STJEGANJU SOGIJALNE KOMPETENTNOSTI}

Socijalna kompetentnost kod djece unutar obitelji pospješuje se demokratskim, a ne permisivnim ili autoritarnim roditeljskim odgojem. Autoritativan roditeljski odgojukojem prevladavademokratskistilodgojavodivisokoj razinisamopouzdanja i visokoj razini socijalne kompetencije u adolescenciji (Samples i Aber, 1998). Djeca autoritativnih roditelja imaju značajno veću socijalnu kompetentnost, te isto tako djeca majki autoritativnog odgojnog stila imaju istovremeno i značajnije niže internalizirane probleme u ponašanju (Vlah i sur., 2013). Novija istraživanja Vlah (2017) potvrđuju prijašnja istraživanja o ulozi obitelji. Pritom roditelji ponekad na prikladan način reagiraju na djetetove emocije, no postoje i roditelji skloniji kažnjavanju ako dijete pokazuje uznemirenost ili strah, te im npr. uskrate drugu aktivnost ili nametnu osjećaj krivnje. U tom slučaju djeca su tjeskobna i povučena. 
Isto tako, djeca čiji se roditelji uznemire ili kazne djecu kada pokazuju negativne emocije češće iskazuju agresivno ponašanje.

O važnosti obitelji, obiteljskih odnosa te funkcioniranju obitelji govore razni autori ističući kako je ključan upravo utjecaj obitelji na razvoj socijalne kompetentnosti. Obiteljske prilike i suvremen način života djeluju na odnos djece i roditelja te na sveukupna ponašanja i socijalnu kompetentnost u najranijoj dobi (Jurčević-Lozančić, 2011; Zloković, 2014). Zajedničko vrijeme obitelji izuzetno je važno u formiranju tjelesno i mentalno zdravih pojedinaca, stoga se može reći da se današnje obitelji nalaze pred izazovima u kojima postoji problem svakodnevne užurbanosti i pomanjkanja vremena za djecu. Takav, suvremen način života kod djece rezultira usamljenošću, povlačenjem u sebe, nemirom ili agresivnošću, najviše zbog odvojenosti i nemogućnosti provođenja zajedničkog vremena roditelja i djece (Jurčević-Lozančić, 2011). Također, suvremen način života koji je usmjeren prema potrošnji, nekritičkom prihvaćanju ponuđenih sadržaja za djecu i pomanjkanju socijalnih kontakata ukazuje na potrebu osnaživanja uloge obitelji i odgojnoobrazovnih ustanova, s naglaskom na njihovo partnerstvo (Zloković, 2014).

Odgovarajući postupci odraslih posljedično će djelovati na neovisno istraživanje kod djece, intelektualnu znatiželju i stvaranje ili rješavanje kompleksnih životnih problema koji postaju sve složeniji (Jurčević-Lozančić, 2011). Ako djeca i mladi ne stvore snažnu povezanost s odraslima kroz osjećaj da mogu donositi odluke i riskirati, rezultati učenja vjerojatno će biti ograničeni na poslušnost u ponašanju, bez razvoja neovisnosti i kritičkog razmišljanja (Curtis i Carter, 2003).

Zaključno, roditelji i odgojno obrazovni djelatnici kao profesionalci u odgoju i obrazovanju nalaze se pred zahtjevnom ulogom uzora ponašanja. Koristeći odgovarajuće poželjne obrasce ponašanja utjecat će na razvoj socijalne kompetencije kod djece i na prosocijalno ponašanje.

\section{PREGLED ISTRAŽIVANJA O SOCIJALNOJ KOMPETENTNOSTI U PREDŠKOLSKIM USTANOVAMA}

Istraživanja o socijalnoj kompetentnosti u predškolskim ustanovama ukazuju na određene razlike između dječaka i djevojčica (Cakić i Živčić-Bečirević, 2009; Bubnić, 2002; Rudan i sur., 2002) u iskazivanju socijalne kompetentnosti. Cakić i Živčević-Bečirević (2009) istražuju rodne razlika u iskazivanju problema u ponašanju, socijalne kompetentnosti i prihvaćenosti. Istraživanje socijalne kompetentnosti na uzorku 499 djece predškolske dobi od 2 i pol do 5 godina u Iranu, pokazuju također određene razlike uvjetovane rodom, gdje se djevojčice u prosjeku procjenjuju socijalno kompetentnijima od dječaka, dok dječaci iskazuju 
više problema u ponašanju (Vahedii sur., 2012). Provedeno istraživanjeu Hrvatskoj, već spomenutih Cakić i Živčić-Bečirević (2009) na uzorku od 240 djece, u dobi od 5 do 7 godina, uključivalo je 10 vrtića u Osijeku. Rezultati istraživanja pokazuju da se dječaci i djevojčice znatno razlikuju promatrajući socijalnu kompetentnost i probleme u ponašanju, pri čemu su djevojčice procijenjene kao socijalno kompetentnije, emocionalno zrelije i fleksibilnije od dječaka, a dječaci iskazuju više problema u ponašanju. Dobiveni rezultati istraživanja socijalne kompetentnosti, prema Bubnić (2002), ukazuju da su djevojčice socijalno kompetentnije, s višom razinom smirenog ponašanja u odnosu na procjenjivane dječake. Dječaci iskazuju više problema u ponašanju, pri čemu iskazuju više agresivnosti, egoizma i ljutnje. Ove rezultate potvrdilo je i istraživanje provedeno u Hrvatskoj na uzorku od 254 odgojitelja u Zagrebačkoj županiji u kojem su djevojčice procijenjene socijalno kompetentnijima u odnosu na dječake te s manje eksternaliziranih problema $\mathrm{u}$ ponašanju, naspram dječaka (Župančić, 2017).

Shaw i suradnici (1994) su u longitudinalnom istraživanju kod djece u dobi od prve do treće godine pronašli određene rodne razlike promatrajući probleme u ponašanju te naglašavaju da su razlike rodne predispozicije u načinu iskazivanja problema vidljive već u ranoj dobi.

Objašnjenje više socijalne kompetentnosti i manje eksternaliziranih problema kod djevojčica naspram dječaka koji iskazuju više eksternaliziranih problema i nižu procjenu socijalne kompetentnosti leži u nasljednim razlikama i funkcioniranju mozga, hormonalnim razlikama i stilovima odgoja (Živćić Bečirević i sur., 2003). Isto tako, uvjetovanost ovakvih rezultata može se objasniti stereotipnim ponašanjem roditelja tijekom socijalizacije koja je vidljiva u usmjeravanju djevojčica na prosocijalno ponašanje, dijeljenje igračaka, brigu za druge, dok je odnos prema dječacima nešto drugačiji i očituje se u češćem upotrebljavanju fizičke kazne (Shaw i sur., 1994). U većini kultura, od najranije dobi, dječaci se odgajaju u duhu borbenosti, s ciljem iskazivanja svoje snage i obrane (ŽivčićBečirević i sur., 2003). Objašnjavajući razlike u ponašajnim obrascima kod dječaka i djevojčica, s naglaskom na više agresivnog i neprihvatljivog ponašanja kod dječaka, Jessel i Moir (1993) kao mogući razlog navode biološku osnovu, koja se može objasniti nasljednim razlikama u diferencijaciji, funkcioniranju mozga i hormonalnim razlikama, a može biti i posljedica različitih odgojnih utjecaja tijekom socijalizacije. Suvremeni način života u kojem roditelji često doživljavaju stres zbog neizvjesnosti o preživljavanju te česta odsutnost oca zbog posla ili nekog drugog razloga posljedično djeluje na češće nasilje kod dječaka te negativan odnos u odgoju djece općenito rezultira agresijom i delinkventnim ponašanjem (Velki, 2012). Veći broj problema u ponašanju kod dječaka naspram djevojčica Vahedi 
i suradnici (2012) objašnjavaju tipičnim ponašanjima dječaka koja uključuju pojačanu tjelesnu aktivnost, sudjelovanje u gruboj igri i iskazivanje emocija ljutnje.

Dva temeljna aspekta socijalne kompetencije, koje ističu Katz i McClellan (2005) su popularnost ili sociometrijski status i prijateljstvo. Lindsay (2002) istražuje na koji način prijateljstvo djeluje na socijalnu kompetentnost djece. Istraživanje u kojem su promatrana djeca predškolske dobi, točnije njih 166 od 3 do 6 godina, prema procjenama odgojitelja 73\% djece je imalo barem jedno, a $27 \%$ je imalo dva ili više prijateljstva. Socijalna kompetentnost djece koja imaju barem jedno prijateljstvo procijenjena je višom u odnosu na djecu koja nemaju prijateljstva. Isto tako, promatrajući agresiju, kompetencije i vršnjačko prihvaćanje vidljiva je sličnost kod djece koja imaju uzajamna prijateljstva. Istraživanje je pokazalo da je uzajamno prijateljstvo faktor koji djeluje na socijalni razvoj djece te da predškolske ustanove imaju ulogu ostvarenja upravo tih kontakata (Lindsay, 2002). Prema procjenama odgojitelja, marljivost i otvorenost djece povezuju se sa socijalnom kompetencijom i niskom pojavnosti eksternalizirajućeg ponašanja $u$ vrtiću (Zupančić i Podlesek, 2010).

Rezultati brojnih suvremenih istraživanja govore o korelaciji između razvoja djetetova postignuća i okruženja. Pozitivne socijalne interakcije, a posebice uključivanje djeteta u zajedničke aktivnosti u svrhu cjelokupnog razvoja djeteta te konstruktivan djetetov doprinos prema sebi i drugima predstavlja društveno prihvatljivo i socijalno kompetentno ponašanje (Jurčević-Lozančić, 2011).

Sindik i suradnici (2014) zaključuju da su razlike statistički značajne u svim kompetencijama koje su istraživali kod djece predškolske dobi u odnosu na rod djeteta i grad u kojemu djeca pohađaju dječji vrtić. Djevojčice su na temelju njihovih procijenjenih kompetencija spremnije za školu. Zanimljiv podatak je da su djeca iz zagrebačkog dječjeg vrtića, u odnosu na splitske, odnosno ivanićgradski također procijenjena kompetentnijima i spremnijima za školu. Rodne razlike u dječjim kompetencijama mogu se protumačiti većom zrelošću djevojčica $u$ predškolskoj dobi. Razlike u kompetentnosti među djecom iz različitih gradova mogu se tumačiti razlikama u poticajnosti djetetova okruženja (Sindik i sur., 2014). 


\section{ZAKLJUČAK}

Specifična ponašanja pojedinaca koja se očituju u tolerantnosti, nenasilnom rješavanju sukoba, konstruktivnoj komunikaciji i zadovoljavanju svojih potreba uz uvažavanje tuđih potreba predstavljaju socijalne vještine koje se uče od najranije dobi. Socijalna kompetencija kao jedna od ključnih kompetencija određuje način na koji pojedinac koristi vještine u socijalnoj okolini.

Postoje pokazatelji kako socijalno kompetentna djeca postižu bolje rezultate u akademskim postignućima, posjeduju veće samopouzdanje, stvaraju kvalitetne odnose, imaju bolju komunikaciju te ih odlikuje bolji sveobuhvatni razvoj u raznim područjima. Čimbenici koji utječu na razvoj socijalne kompetencije u predškolskoj dobi su: obitelj, vršnjaci, igra i učenje, simbolička igra, zajednica, vrijeme, promjene u fizičkom okruženju, vrijeme u kojem se djeca mogu družiti, projektni rad, interakcije odgojitelja s djetetom, partnerstvo roditelja i odgojitelja te individualni rad s djecom.

Istraživanja pokazuju kako je za predškolsko dijete ključno da usvoji barem minimum socijalnih vještina za kasnije prosocijalno funkcioniranje u životu. Uloga odgojno-obrazovnih djelatnika, ali i svih odraslih koji žive i rade s djecom je značajna jer se socijalne kompetencije ne dobivaju rođenjem nego se stječu. Predškolske ustanove prve su institucije socijalizacije nakon obiteljskog doma te imaju važnu i ključnu ulogu u razvijanju kvalitetnih interpersonalnih odnosa u životima djece.

Svakom djetetu je potrebna barem jedna osoba koja će ga voljeti, iskazati svoju pažnju i ljubav te pokazati kvalitetan obrazac socijalnih vještina. $U$ tom slučaju i djeca koja dolaze iz nefunkcionalnih obitelji imaju priliku usvojiti poželjne oblike ponašanja. Iz tog razloga potrebno je razmišljati o načinima osnaživanja odgojitelja i svih profesionalaca koji se nalaze u neposrednom radu s djecom kako bi upravo te osobe osim velike odgovornosti mogle razvijati i prepoznati vlastitu socijalnu kompetentnost. 


\section{LITERATURA}

1. Božin, S., Milović, S., Pašalić, A., Schröder, B. (2011). Svatko uči na svoj način, Zagreb: Agencija za odgoj i obrazovanje.

2. Brdar, I. (1993b). Što je socijalna kompetencija? Godišnjak Zavoda za psihologiju, Rijeka, 13-22.

3. Bubnić, D. (2002). Socijalne interakcije među djecom u dobno mješovitim i dobno čistim skupinama, Rijeka: Filozofski fakultet-odsjek za psihologiju.

4. Cakić, L., Živčić-Bečirević, I. (2009). Prihvaćenost dječaka i djevojčica u skupini vršnjaka predškolske dobi. Napredak, 150 (2): 140-153.

5. Curtis, D., Carter, M. (2003). Designs for living and learning: Transforming early childhood environments. Yorkton Court, St. Paul: Readleaf Press

6. Gouley, K. K., Miller Brotman, L.M., Huang, K.Y., Shrou, P. E. (2008). Construct Validation of The Social Competance Scale in Preschool-age Children, NYC Child Study Center, New York Universety School of Medicine and Patrick E.Shrout, New York University.

7. Jesssel, D., Moir, A. (1993). Muški spol, ženski spol. Zagreb: Izvori.

8. Jurčević-Lozančić, A. (2011). Teorijski pogledi na razvoj socijalne kompetencije predškolskog djeteta. Pedagogijska istraživanja, 8 (2): 271-281.

9. Jurčević-Lozančić, A. (2011). Redefining the educational role of the family. Croatian Journal of Education: Hrvatski časopis za odgoj i obrazovanje, 13 (4/2011): 122-150.

10. Katz, L. G., McClellan, D. E. (2005). Poticanje razvoja dječje socijalne kompetencije, Zagreb: Educa.

11. Lindsey, E. W. (2002). Preschool children's friendships and peer acceptance: Links to social competence. Child Study Journal, 32 (3): 145-156.

12. Markuš, M. (2010). Socijalna kompetentnost - jedna od ključnih kompetencija. Napredak 151 (3-4): 432-444.

13. McClellan, D. E., Katz, L. G. (2001). Assessing Young Children's Social Competence. ERIC Digest.

14. Mlinarević, V., Tomas, S. (2010). Partnerstvo roditelja i odgojitelja - čimbenik razvoja socijalne kompetencije djece. Magistra Iadertina 5 (5): 143-158.

15. Modrić, N. (2013). Kompetencije odgojitelja za učinkovito upravljanje problemnim situacijama. Napredak, 154 (3): 427-450

16. Pahl, K. M., Barrett, P. M. (2007). The Development of Social - Emotional Comepetence in Preschool - Aged Children: An Introduction to the Fun Friends Program. Australian Journal of Guidance \& Counselling, 17 (1): 81-90.

17. Rudan, V., Begovac, I., Szirovicza L., Filipović, O. (2002). Competence and behavioral/emotional problems in Croatian children - Parents' and teachers' reports: Pilot study, Coll. Antropol, 26: 447-456.

18. Samples, F., Aber, L. (1998). Evaluations of school-based violence prevention programs. In D. S. Elliott, B. A. Hamburg, K. R. Williams (Eds.), Violence in American schools: A new perspective (pp. 217-252). Cambridge, UK: Cambridge University Press 
19. Shaw, D. S., Keenan, K., Vondra, J. I. (1994). Developmental Precursor of Externalizing Behaviour ages 1 to 3. Developmental Psychology, 30 (3): 355-364.

20. Sindik, J. (2008). Jesu li profesionalci socijalno kompetentni? Dijete, vrtić obitelj, 54, 6-11.

21. Sindik, J., Glibić, M., Marušić, V., Đunđenac, V. (2014), Razlike u dječjim kompetencijama koje ukazuju na spremnost za polazak u školu. Metodički ogledi, 21 (1): 9-22.

22. Vahedi, S., Farrokhi, F., Farajian, F. (2012). Social Competence and Behavior Problems in Preschool Children. Department of Psychology, Univerity of Tabriz, Iran.

23. Vasta, R., Haith, M. M., Miller, S. A. (1998). Dječja psihologija. Jastrebarsko: Slap.

24. Velki, T. (2012). Uloga nekih obiteljskih čimbenika u pojavi nasilja među djecom. Psihologijske teme, 21 (1): 29-60.

25. Vlah, N. (2013). Poželjna ponašanja mladih u konfliktima. Zagreb: Biakova.

26. Vlah, N. (2017). Razine rizika za probleme u ponašanju kod djece rane razvojne dobi i stručne intervencije. Preuzeto 6. 10. 2017 s: https://portal.uniri.hr/Projekti/390?controler=projekti

27. Zloković, J., Vrcelj, S. (2010). Rizična ponašanja djece i mladih. Odgojne znanosti, 12 (1): 197-213.

28. Zloković, J. (2014). Komercijalizacija ranog djetinjstva i stvaranje vrijednosnih „mentalnih mapa“. Croatian Journal of Education: Hrvatski časopis za odgoj i obrazovanje, 16 (Sp.Ed.1): 291303.

29. Zupančić, M., Podlesek, A. (2010). Procjena ličnosti u ranom djetinjstvu kao pokazatelj razvojnih obilježja u posljednjoj predškolskoj godini. Suvremena psihologija, 13 (1): 27-44.

30. Živčić-Bećirević, I., Smojver-Ažić, S., Mišćenić, G. (2003). Problemi u ponašanju predškolske djece prema procjeni roditelja i odgojitelja, Psihologijske teme, 12 (1): 63-76.

31. Župančić, M. (2017). Relacije učinkovitosti odgojitelja s djetetovim problemima u ponašanju i socijalnom kompetentnosti u predškolskim ustanovama. Diplomski rad, Sveučilište u Rijeci, Filozofski fakultet u Rijeci. 


\title{
SOCIAL COMPETENCE IN THE EARLY AND PRESCHOOL AGE
}

\begin{abstract}
This paper determines the social competence construct from the point of view of different authors. The results of various studies have shown that children with developed social competence achieve better academic results and have greater selfconfidence. Therefore, the paper explains the importance of educational workers and the role of the family in the development of preschool children's social competence. In addition, the paper presents recent research studies on social competence in relation to gender differences, sociometric status and friendship.
\end{abstract}

Key words: social competence, educational worker, family role. 